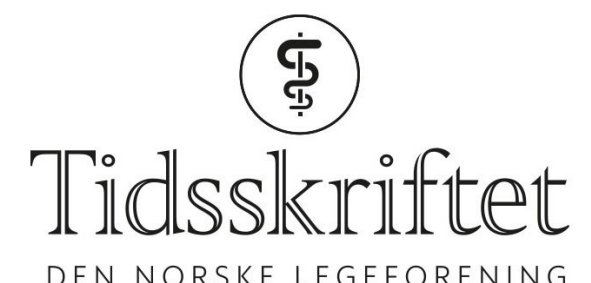

DEN NORSKE LEGEFORENING

\title{
Nyttige kommandoer i Stata
}

ANMELDELSER

\section{EVA SKOVLUND}

Professor, Institutt for samfunnsmedisin og sykepleie

Norges teknisk-naturvitenskapelige universitet

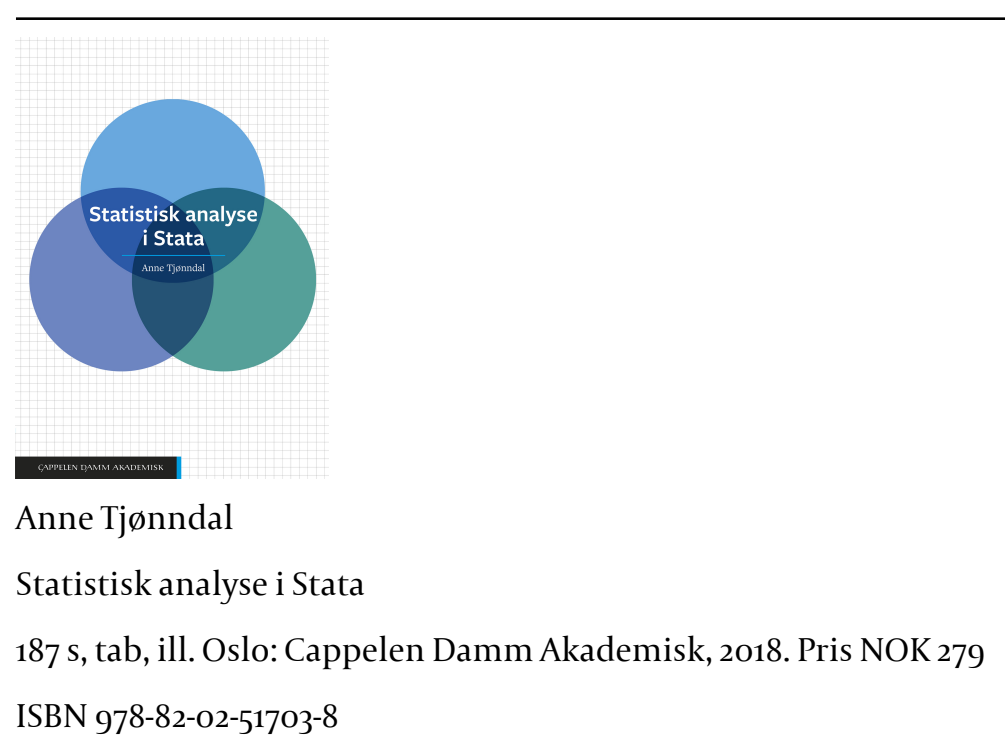

Skal du lære å bruke et nytt statistikkprogram? Stata er et utmerket valg, og denne boken gir en enkel og god innføring i en del kommandoer i denne programvaren. Men det er ikke en lærebok i statistisk analyse. Boken er ment som tilleggslitteratur til andre lærebøker og er basert på en undervisningsrekke av dataøvinger ved Institutt for sosiologi og statsvitenskap ved Norges teknisk-naturvitenskapelige universitet. Den gir en innføring i praktisk bruk av analyseverktøyet Stata og er tiltenkt nye brukere, primært studenter i samfunnsvitenskapelige disipliner. Begrepsbruken er naturlig nok fra en samfunnsvitenskapelig tradisjon snarere enn en medisinsk. Bokens gjennomgående eksempel er et datasett fra European Social Survey (ESS) som kan lastes ned fra nettet.

Boken er delt inn i fire deler med underkapitler: introduksjon til statistisk analyse i Stata, deskriptiv statistikk, omkoding og enkel regresjonsanalyse, avanserte metoder og regresjonsmodeller, samt forutsetninger for regresjonsanalyse. Hvert kapittel avsluttes med en oppsummering av Stata-kommandoer som er brukt i det aktuelle kapitlet. Boken er lettlest, holdt i et muntlig språk og gjennomgående illustrert med skjermbilder og klipp fra resultatvinduet i en behagelig og luftig layout.

Forfatteren starter med å la leseren bli kjent med programmet slik det ser ut første gang man åpner det. I denne innledende delen synes jeg teksten er på sitt beste, selv om den noen ganger kan bli litt omstendelig, for eksempel med hensyn til koding av manglende verdier. 
Når det kommer til beskrivelser av statistiske metoder, er den dessverre ikke like god. Upresisheter og forenklinger kan man leve med - selv om det kan skurre litt av og til. Verre er direkte feil. Det er for eksempel svært bekymringsfullt at en vanlig misforståelse knyttet til fortolkning av p-verdier dukker opp i en lærebok. En p-verdi er ikke sannsynligheten for at nullhypotesen er sann. Definisjonen av et $95 \%$ konfidensintervall er heller ikke korrekt.

Den siste delen omhandler avanserte modeller, for eksempel faktoranalyse. Det synes å være et misforhold mellom en svak beskrivelse av fortolkning av enkle statistiske analyser og fokus på detaljerte oppskrifter for komplekse modeller og analyser. Dersom leseren har tilstrekkelig forhåndskunnskap om statistisk metode, og har benyttet andre analyseverktøy tidligere, kan boken kanskje likevel fungere greit som et hefte med oppskrifter og kommandoer i en programvare man ønsker å bli kjent med.

Og etter korrigering av direkte feil tenker jeg at dette kan være en nyttig bok for studenter i samfunnsvitenskap. Jeg er mer usikker på om den er et godt valg for medisinske forskere.

Publisert: 26. juni 2018. Tidsskr Nor Legeforen. DOI: 10.4045/tidsskr.18.0225

(C) Tidsskrift for Den norske legeforening 2020. Lastet ned fra tidsskriftet.no 